\title{
Mercury distribution in the surface soil of China is potentially driven by precipitation, vegetation cover and organic matter
}

\author{
Zhao-Yang Zhang ${ }^{1,3}$, Gang Li ${ }^{2}$, Lei Yang ${ }^{1}$, Xin-Jun Wang ${ }^{4}$ and Guo-Xin Sun ${ }^{1,3^{*}}$ (D)
}

\begin{abstract}
Background: Understanding the mechanism of $\mathrm{Hg}$ accumulation in soil, which is a net $\mathrm{Hg}$ sink, at a national scale is important for protecting the environment and improving food safety. The mercury $(\mathrm{Hg})$ distribution in surface soil in China is quite uneven, with relatively high concentrations in southeastern China and low concentrations in northwestern China. The reason for this distribution is inconclusive, especially at the continental scale. In this study, the relative contributions of the key impact factors, including dry and wet deposition, soil organic matter (SOM) and solar radiation to soil Hg, were evaluated.

Results: Wet and dry deposition associated with precipitation and vegetation cover and emissions influenced by SOM are key factors controlling Hg distribution in surface soil. In southeastern China, high levels of wet deposition associated with the South Asia monsoon and dry deposition, enhanced by vegetation canopies, together with low levels of emissions caused by highly vegetated surfaces and solar radiation, are responsible for the high $\mathrm{Hg}$ levels in soil (>0.08 mg/kg). In northeastern China, moderate levels of wet $\mathrm{Hg}$ deposition, high levels of dry deposition via throughfall and litterfall, low emissions due to weak solar radiation and high levels of SOM are responsible for high $\mathrm{Hg}$ accumulation in soil. In northwestern China, low levels of wet deposition, together with high emissions levels, low vegetation cover (bare soil) and SOM and strong solar radiation, contributed to the low $\mathrm{Hg}$ level in the surface soil $(<0.03 \mathrm{mg} / \mathrm{kg})$.

Conclusions: We suggest that wet deposition derived from the Asian monsoon, dry deposition linked to vegetated surfaces and $\mathrm{Hg}$ emissions associated with vegetation cover, SOM and solar radiation play key roles in the soil Hg level in China. In other terrestrial environments worldwide, especially in regions with significantly high levels of wet deposition and high amounts of vegetation cover and soil SOM, high Hg concentrations may exist in the surface soil.
\end{abstract}

Keywords: Soil mercury distribution, Wet and dry deposition, Vegetation cover, Emissions, Soil organic matter, Solar radiation

\section{Background}

Mercury $(\mathrm{Hg})$ is an extremely toxic element to humans $[1,2]$ and ecological receptors [3], with an average crustal abundance of $\sim 0.05 \mathrm{mg} / \mathrm{kg}$ [4]. Soils and

\footnotetext{
*Correspondence: gxsun@rcees.ac.cn

${ }^{1}$ State Key Laboratory of Urban and Regional Ecology, Research Center for Eco-Environmental Sciences, Chinese Academy of Sciences, Beijing 100085, China

Full list of author information is available at the end of the article
}

terrestrial sediments have been documented as acting as net $\mathrm{Hg}$ sinks [5] because atmospheric $\mathrm{Hg}$ species (e.g., elemental $\mathrm{Hg}$ ) produced by anthropogenic activities can be subjected to long-distance transport to remote regions and ultimately find their way (wet and dry deposition) into terrestrial or aquatic systems [6]. It has been reported that soil $\mathrm{Hg}$ generally accounts for $>90 \%$ of the $\mathrm{Hg}$ stored in terrestrial ecosystems, and most $\mathrm{Hg}$ in soil (> 80\%) is from atmospheric inputs [7]. A recent study showed that upland food such as 
rice is a significant dietary source of $\mathrm{Hg}$ in addition to fish consumption [8]. Understanding the mechanism of $\mathrm{Hg}$ accumulation in soil at a national scale is important to protect the environment and improve food safety.

It has been reported that the flux of $\mathrm{Hg}$ deposition and emissions from soil are controlled by various environmental factors, such as solar radiation, temperature, $\mathrm{Hg}$ speciation and content, soil porosity, soil moisture, $\mathrm{pH}, \mathrm{SOM}$ content, ambient $\mathrm{Hg}$ concentration, vegetation cover, and precipitation [9-14]. It is generally accepted that at a small scale (local or regional scale), mining activities or combustion of $\mathrm{Hg}$ bearing coal are among the most important factors affecting $\mathrm{Hg}$ distribution in soils [15]. However, at continental and subcontinental scales, such as in China, the relevant main drivers of the spatial distribution of soil $\mathrm{Hg}$ in the terrestrial environment are poorly understood [16]. It is still unclear at present what factors in addition to lithology play essential roles in the spatial variability in soil $\mathrm{Hg}$ distribution at such a large scale and their contribution to soil Hg (Fig. 1).

China is one of the world's largest sources of $\mathrm{Hg}$ in the air [18-20]. The Hg distribution in surface soil is mainly from atmospheric $\mathrm{Hg}$ deposition [17]. The first soil Hg map in China was obtained from the National Soil Background Survey, which was initiated in the late 1980s and issued in 1994 (Fig. 1a) [21]. Considering the possible influence of rapid industrialization and dramatic urbanization that occurred in China in past decades on $\mathrm{Hg}$ emissions and its distribution in surface soil, the soil Hg map (Fig. 1b) was updated by a new geochemical mapping project the National MultiPurpose Regional Geochemical Survey (NMPRGS) of China, which was initiated in 1999 and completed in $2014[2,21]$. Comparing the old and new soil $\mathrm{Hg}$ maps at the national scale, the spatial distributions of soil $\mathrm{Hg}$ were consistent, regardless of the difference in $\mathrm{Hg}$ concentration in the same region, although localscale contamination of soil $\mathrm{Hg}$ due to gold production or fossil fuel combustion was observed because of unprecedented economic growth in China during the past two decades [22]. Hg distribution in the surface soil in China was uneven before the Chinese economic boom (Fig. 1a), with relatively high concentrations in southeastern and northeastern China and much lower concentrations in northwestern China (Fig. 1). The primary driving factors for $\mathrm{Hg}$ distribution in surface soil at a large scale are elusive. The purpose of this study is to elucidate the major factors affecting the distribution of soil $\mathrm{Hg}$ and the relative contribution of these factors.

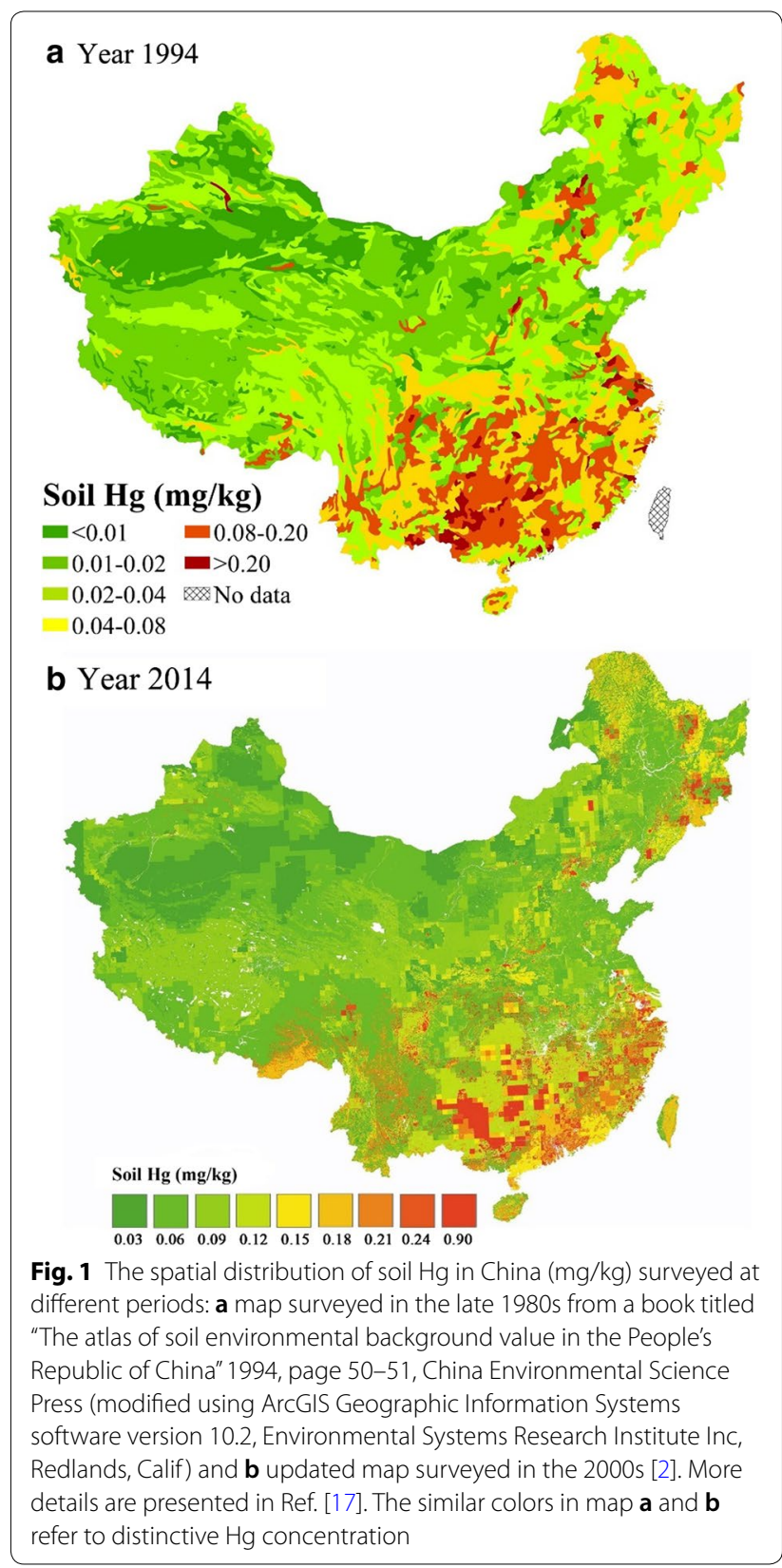

\section{Materials and methods}

The 1994 map of Chinese soil mercury distribution (Fig. 1a) was obtained from the atlas titled "The atlas of soil environmental background value in the People's Republic of China" 1994, page 10-11, China Environmental Science Press, and the 2014 map (Fig. 1b) from a new survey of geochemical mapping project [21] was cited from published literature [2]. The mean annual precipitation dataset was provided by the China Meteorological Data Sharing Service System (Fig. 2a). The Normalized Difference Vegetation Index (NDVI) dataset (Fig. 2b) [23] 
(See figure on next page.)

Fig. 2 The maps of factors and relationships of $\mathrm{Hg}$ levels in surface soil with these factors. Spatial distribution of a wet deposition in China; $\mathbf{b}$ NDVI and c soil organic matter (created using ArcGIS Geographic Information Systems software version 10.2, Environmental Systems Research Institute Inc, Redlands, Calif). Significant relationships between soil $\mathrm{Hg}$ level and $\mathbf{d}$ precipitation, $\mathbf{f} \mathrm{NDVI}$ and $\mathbf{h}$ SOM. All data including soil Hg level, precipitation, NDVI and SOM were corrected for variation in sampling intensity by subsampling. Median, range, upper quartile, and lower quartile of soil $\mathrm{Hg}$ for each interval of e precipitation, $\mathbf{g} \mathrm{NDV}$ and $\mathbf{i} \mathrm{SOM}$

was downloaded from MODIS (Moderate Resolution Imaging Spectroradiometer). Data sets have a resolution of $0.05^{\circ}$ by $0.05^{\circ}$. NDVI data sets were extracted from per 16-day maximum value composites using a time-series analysis approach [24]. The dataset of SOM (Fig. 2c) were from the National Earth System Science Data Center, National Science and Technology Infrastructure of China (http://www.geodata.cn). The solar radiation distribution dataset (Fig. 4a) was downloaded from SOLARGIS (https ://solargis.com/maps-and-gis-data/download/China).

The 1994 map of Chinese soil mercury distribution was digitized with ArcGIS 10.2 (Environmental Systems Research Institute Inc., Redlands, California, USA). We converted the digitized maps of soil mercury distribution, mean annual precipitation, NDVI, SOM, and solar radiation into raster format. The "create random points" tool in ArcGIS 10.2 was used to create sampling points in the maps with a distance of $10 \mathrm{~km}$ between every two points. For the $\mathrm{Hg}$ values of all obtained points, each point was randomly assigned a value within its particular concentration range to obtain continuous output [24]. All other corresponding values of the obtained points in the different datasets (precipitation, NDVI, SOM, and solar radiation) were extracted by the "extract multi values to points" tool in ArcGIS 10.2. The points with null values were filtered out by the "dplyr" package in the statistical software program " $R$ " (R-Core-Team), and finally, a total of 2827 points were obtained.

Data subsampling to construct sampling bins was utilized to eliminate possible biases caused by uneven data density for different intervals of subsets. The same estimated number of data points was included in each sampling bin. The precipitation dataset was separated into 19 subsets (sampling bins) for every $100 \mathrm{~mm} /$ year interval in $\mathrm{R}$, and the last subset contained all points with precipitation amounts higher than $1800 \mathrm{~mm}$ /year (Fig. 2d, e). One hundred sample points were randomly selected from each subset of precipitation, and the average value of those points was taken as the representative of this subset (Fig. 2d). The NDVI dataset was divided into 9 subsets based on NDVI values from 0 to 0.9 at intervals of $0.1 ; 200$ sample points were randomly obtained from each sampling bin, and the average value of these 200 sample points represents this subset (Fig. 2f, g). The dataset of SOM was split into 10 subsets at intervals of $1 \%$ from 0 , and the last subset contained all values $>10 \%$. The average of the 200 randomly sampled points represents this subset (Fig. 2h, i). The dataset of solar radiation was split into 8 subsets. The first subset included the points with solar radiation values less than $1000 \mathrm{kWh} / \mathrm{m}^{2}$, and the last subset included all points with values higher than $1800 \mathrm{kWh} / \mathrm{m}^{2}$.

\section{Results and discussion \\ Mercury input from wet precipitation}

A significant linear relationship $\left(R^{2}=0.91\right)$ between the soil $\mathrm{Hg}$ level and precipitation was observed (Fig. 2d). Obviously, a high level of wet deposition was one of the main contributors to high surface soil Hg. The high mean $\mathrm{Hg}$ concentration in southeastern China, such as the Yangtze River Delta region, was mainly caused by occasional long-distance transport from domestic source regions and regional anthropogenic emissions due to rapid economic development, which relied heavily on coal combustion for electricity generation $[25,26]$. Precipitation derived from the East Asian monsoon is one of the important factors controlling soil $\mathrm{Hg}$ distribution in China [27]. In central China, the surface soil $\mathrm{Hg}$ concentration was relatively lower than that in southeastern China because the wet deposition in this region was relatively low $(400-800 \mathrm{~mm})$. In northwestern China, wet deposition was much less (annual precipitation less than $200 \mathrm{~mm}$ ), and in some regions, annual precipitation is even less than $100 \mathrm{~mm}$, such as the sand in the Gobi Desert, with no influence from the East Asian summer monsoon. Low $\mathrm{Hg}$ concentrations in surface soils $(<0.03 \mathrm{mg} / \mathrm{kg}$ ) were observed (Fig. 1). This trend is also observed in European study results (Additional file 1: Figure S1A). Soil Hg in Europe markedly linearly increased $\left(R^{2}=0.92\right)$ accompanied by precipitation $(<800 \mathrm{~mm} /$ year). However, higher precipitation $(>800 \mathrm{~mm} /$ year $)$ did not enhance soil $\mathrm{Hg}$ accumulation, and soil $\mathrm{Hg}$ accumulation remained constant at high levels (if the last point was omitted due to the geological high $\mathrm{Hg}$ background) (Additional file 1: Figure S1A).

A relatively high level of particulate-bound $\mathrm{Hg}(0.13-$ $0.18 \mathrm{ng} / \mathrm{m}^{3}$ ) was readily removed through wet deposition [26]. Eastern Chinese soil was largely influenced by anthropogenic $\mathrm{Hg}$ emissions from surrounding areas due to its close proximity to the largest anthropogenic $\mathrm{Hg}$ emissions. Elevated $\mathrm{Hg}$ pollution in the southeastern atmosphere can be expected to have higher deposition 


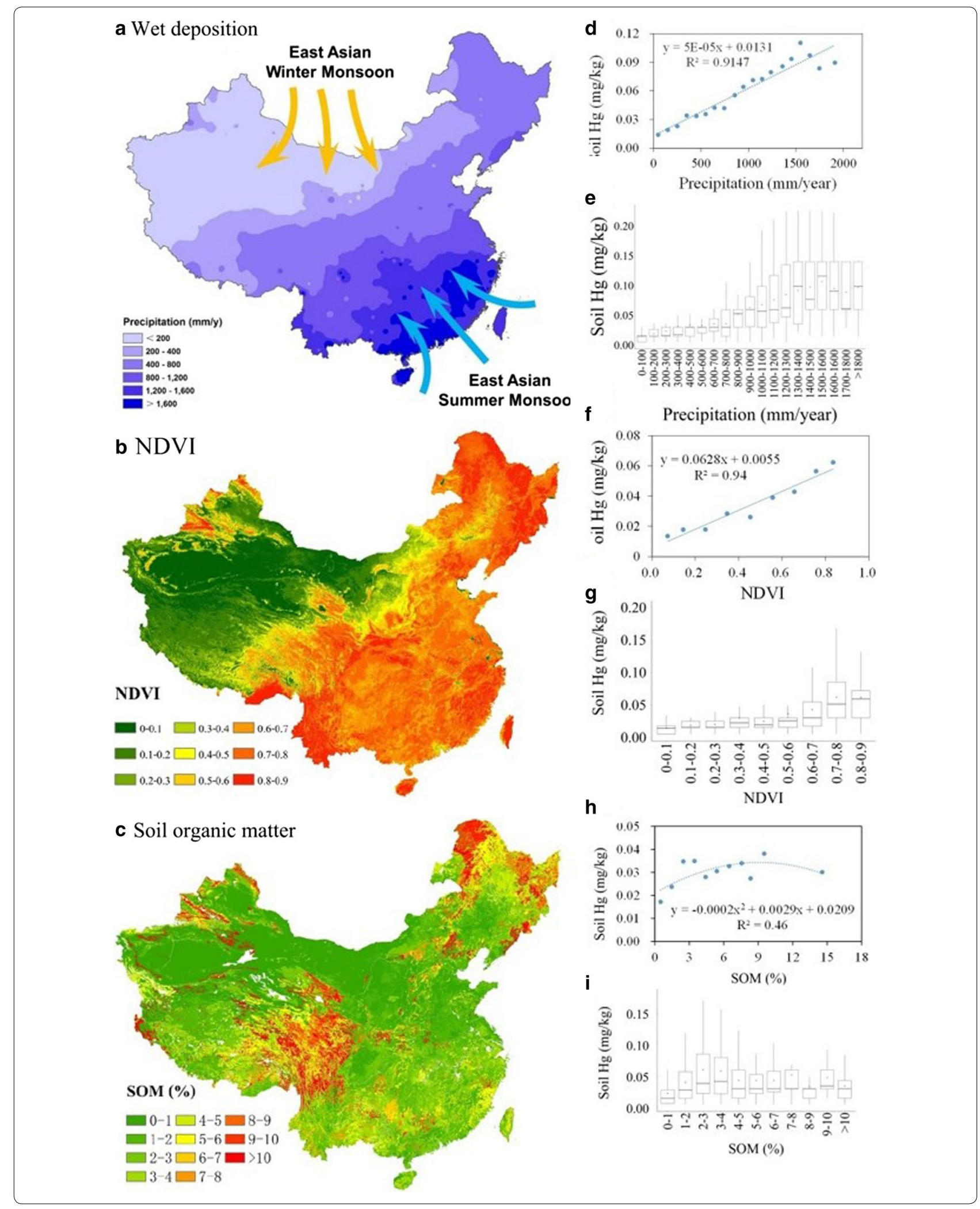


Table 1 Summarized Hg wet deposition, dry deposition, emission and net input (deposition minus emission) in soil from different regions, China

\begin{tabular}{|c|c|c|c|c|}
\hline Precipitation (mm/year, i.e. $\mathrm{L} / \mathrm{m}^{2} /$ year) & $<400$ & $400-800$ & & $>800$ \\
\hline Regions & Northwest & Northeast & Southwest & Southeast \\
\hline Ecosystem & Bare soil or grassland & Forest and shrub & Forest and shrub & Forest, shrub or vegetation \\
\hline $\begin{array}{l}\text { Hg wet precipitation } \\
\left(\mu \mathrm{g} / \mathrm{m}^{2} / \text { year }\right)\end{array}$ & $1.08-4.63$ & 8.40 & $0.74-15.9$ & $26.1-39.0$ \\
\hline $\begin{array}{l}\text { Hg dry precipitation } \\
\left(\mu \mathrm{g} / \mathrm{m}^{2} / \text { year }\right)\end{array}$ & - & $16.5-20.2$ & 63.3 & $51.0-66.4$ \\
\hline Hg emission ( $\mu \mathrm{g} / \mathrm{m}^{2} /$ year) & 9.37 & -1.05 & 9.60 & $51.5-57.8$ \\
\hline Net Hg input & $-8.29 \sim-4.74$ & $26.0 \sim 29.7$ & $54.4 \sim 69.6$ & $25.6 \sim 47.6$ \\
\hline References & {$[47,59,60]$} & {$[11,60,61]$} & {$[16,40,47,62]$} & {$[59,61,63-67]$} \\
\hline
\end{tabular}

in the local soil through precipitation. Most Hg deposition occurred during the monsoon season, with $83 \%$ of the oxidized and particulate-bound $\mathrm{Hg}$ [28]. Higher $\mathrm{Hg}$ concentrations were observed in the sediment samples collected in the Indian estuarine regions during the postmonsoon period than in the pre-monsoon period of the Indian summer monsoon [29], confirming that wet deposition derived from monsoons is one of the major $\mathrm{Hg}$ contributors.

The Asian monsoon system controls wet deposition over mainland Asia, including China. During summer monsoons, a strong land-sea pressure gradient is produced by high insolation over continental regions, forcing oceanic winds to converge over southeastern China, bringing oceanic moisture and causing abundant rainfall in this region [30]. The mean annual precipitation decreases gradually from $2000 \mathrm{~mm}$ on the southeastern coast to $400-800 \mathrm{~mm}$ in central China and then decreases to less than $200 \mathrm{~mm}$ in most of northwestern China (Fig. 2a).

The total wet deposition of $\mathrm{Hg}$ in the regions of southeastern China was simulated by the global/regional atmospheric heavy metal model (GRAHM) and was consistent with high amounts of precipitation [31]. Monsoons have increased total $\mathrm{Hg}$ levels in some regions of the Tibetan Plateau by carrying Hg-enriched air from South Asia [32]. In comparison to nonconvective rainfall events, thunderstorms, which are deep convective rainstorms, are particularly effective at scavenging gaseous oxidized $\mathrm{Hg}$ from the boundary layer into the cloud base and result in a nearly $50 \%$ increase in $\mathrm{Hg}$ deposition [33]. The thunderstorm frequency also greatly contributes to $\mathrm{Hg}$ wet deposition. The average annual days of thunderstorms were high ( $>80$ days) in the southern and southwestern regions of China [34], indicating that more $\mathrm{Hg}$ wet deposition occurred in these regions, which is consistent with high soil Hg levels (Fig. 1). Excessive Hg input to soil occurred in the monsoon season compared to that in other seasons [28, 35]. Wet deposition typically accounts for $50-90 \%$ of the atmospheric $\mathrm{Hg}$ entering the environment in some regions [36, 37]. The East Asian summer monsoon generates wind patterns in summer that sweep atmospheric Hg derived from the South China Sea and transport it through the atmosphere and deposit it in terrestrial ecosystems in southeastern China (Fig. 2a).

\section{Mercury input from dry precipitation}

In addition to wet deposition, $\mathrm{Hg}$ in air also enters terrestrial ecosystems through dry deposition, such as gravity deposition, atmospheric diffusion and other processes [38-40]. Precipitation in central China, such as northeastern China, is moderate $(400-800 \mathrm{~mm})$. However, soil $\mathrm{Hg}$ levels were relatively high $(0.04-0.20 \mathrm{mg} / \mathrm{kg}$, Fig. 1a). This result confirms that dry deposition is also an important contributor to soil $\mathrm{Hg}$ accumulation. The significant linear relationship $\left(R^{2}=0.94\right)$ between the soil $\mathrm{Hg}$ level and NDVI at the national scale indicated that vegetation cover has significant effects on $\mathrm{Hg}$ accumulation in soil (Fig. 2b, f, g). Typical dry deposition fluxes for elemental $\mathrm{Hg}$ over vegetated surfaces were substantially higher than those over non-vegetated surfaces (Fig. 2b, Table 1) [39]. Vegetation is known to contribute to atmospheric $\mathrm{Hg}$ as a sink through direct uptake of $\mathrm{Hg}$ from the air through stomata on the leaf surface [10, 41]. Upland forest soil acts as a strong sink for $\mathrm{Hg}$, and dry deposition of $\mathrm{Hg}$ through litterfall $\left(71.2 \mu \mathrm{g} / \mathrm{m}^{2} /\right.$ year $)$ was the major pathway for $\mathrm{Hg}$ loading to the forest catchment in southwestern China [42, 43]. In temperate forested regions such as northeastern China, dry $\mathrm{Hg}$ deposition is widely accepted to be approximately two times the amount of wet $\mathrm{Hg}$ deposition $[44,45]$, and uptake of $\mathrm{Hg}$ by forest canopies plays a predominant role in soil $\mathrm{Hg}$ accumulation [46]. Approximately $72-90 \%$ of the total $\mathrm{Hg}$ deposition in the forest areas of China was due to dry deposition [27]. 


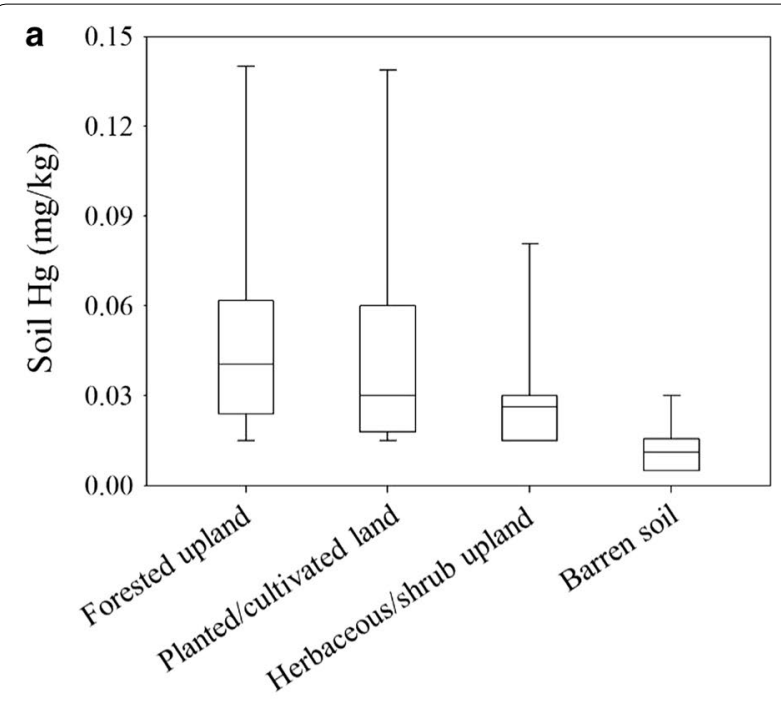

Vegetation type

b

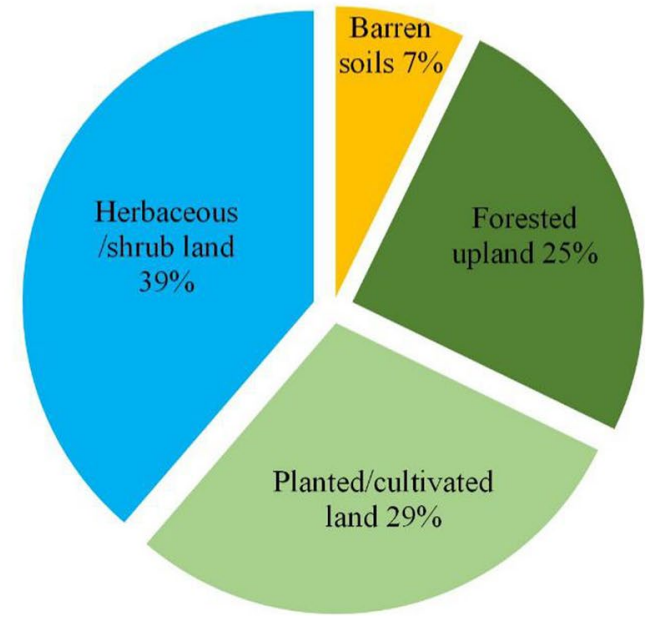

Fig. 3 Median, range, upper quartile, and lower quartile of soil $\mathrm{Hg}$ concentrations in different vegetation cover types (a). The percentages of $\mathrm{Hg}$ in Chinese surface soil with different land cover type (b)

In China, soil $\mathrm{Hg}$ concentrations are quite different among land cover types and occur in the following order: forested upland $(0.055 \mathrm{mg} / \mathrm{kg})>$ planted/cultivated $(0.050 \mathrm{mg} / \mathrm{kg})>$ herbaceous upland/shrubland $(0.036 \mathrm{mg} /$ $\mathrm{kg})>$ barren soils $(0.015 \mathrm{mg} / \mathrm{kg})$, with an average soil $\mathrm{Hg}$ concentration that is 3.6 times higher in forests than in barren locations (Fig. 3a). The percentages of Hg contents in surface soil with different land vegetation were different as well (Fig. 3b). Atmospheric $\mathrm{Hg}$ deposition fluxes in western China, such as those on the Tibetan Plateau and in Xinjiang Province, ranged from 0.74 to $7.89 \mu \mathrm{g} / \mathrm{m}^{2} /$ year and were at least one order of magnitude $(71.2 \mu \mathrm{g} /$ $\mathrm{m}^{2} /$ year) lower than that in East Asia (forest cover) [47].
The results of this study showed that different vegetation covers matched the soil Hg distribution in China. In general, $\mathrm{Hg}$ concentrations in forest and crop-covered soil (Additional file 1: Figure S2A) were higher than those in grasslands (Additional file 1: Figure S2A). For terrestrial ecosystems, the dry deposition of $\mathrm{Hg}$ mainly occurs through the leaves of vegetation absorbing atmospheric $\mathrm{Hg}$ from the atmosphere through stomata, and then, $\mathrm{Hg}$ enters the forest ecosystem as litterfall [48]. The desert region in northwestern China exhibited the lowest $\mathrm{Hg}$ concentrations in soil because of the barren soils. In the western United States, the soil $\mathrm{Hg}$ distribution is strongly linked to vegetation greenness with the same order of $\mathrm{Hg}$ levels in land cover as that in China, and forested land had more than 2.5 times higher soil $\mathrm{Hg}$ levels than that in barren soils [7].

The presence of any soil cover has been found to decrease atmospheric $\mathrm{Hg}$ emission fluxes in comparison with bare soils, and even leads to a shift from a net atmospheric emission to a net deposition from the atmosphere [41, 49]. For example, studies were carried out within various types of forest systems across a vast region from the south (South Carolina) to the north (Maine) in United States during the same season. Mercury emission associated with the litter covered forest floor was extremely low [49], fluctuating around $0 \mathrm{ng} /$ $\mathrm{m}^{2} / \mathrm{h}$, with many deposition rather than emission occurring at both daytime and nighttime, irrespective of the forest type, soil type, and variations in weather conditions $[10,49]$. Canopy covers in forests and grasslands/ shrublands are partially expected to reduce $\mathrm{Hg}$ emissions by limiting soil warming and solar loads via shading the forest floor $[31,50]$.

\section{Mercury sequestration by soil organic matter}

SOM contributes to the accumulation of $\mathrm{Hg}$ in soil. Soil $\mathrm{Hg}$ concentrations are positively related to soil organic carbon [51, 52], and $\mathrm{Hg}$ emissions is inversely correlated with organic content in soils because organic carbon has a high affinity to $\mathrm{Hg}$ in soil through functional groups, particularly thiols [7, 53]. In general, with an increase in SOM in soil, the $\mathrm{Hg}$ concentration in soil substantially increased (Fig. 2c, h, i). A similar relationship between SOM and $\mathrm{Hg}$ concentration was observed in Europe as well (Additional file 1: Figure S1B). In aqueous systems, $\mathrm{Hg}$ (II) is reduced to volatile elemental $\mathrm{Hg}$ by organic acids, and these reactions appear to be strongly induced by sunlight [54]. These processes do not occur in soils because sunlight cannot easily radiate soil, especially with vegetation cover. Binding of $\mathrm{Hg}$ with organic matter inhibits the reduction of $\mathrm{Hg}$ (II) to elemental $\mathrm{Hg}$ and subsequent emissions from soil. A strong correlation between soil $\mathrm{Hg}$ concentrations and organic carbon 

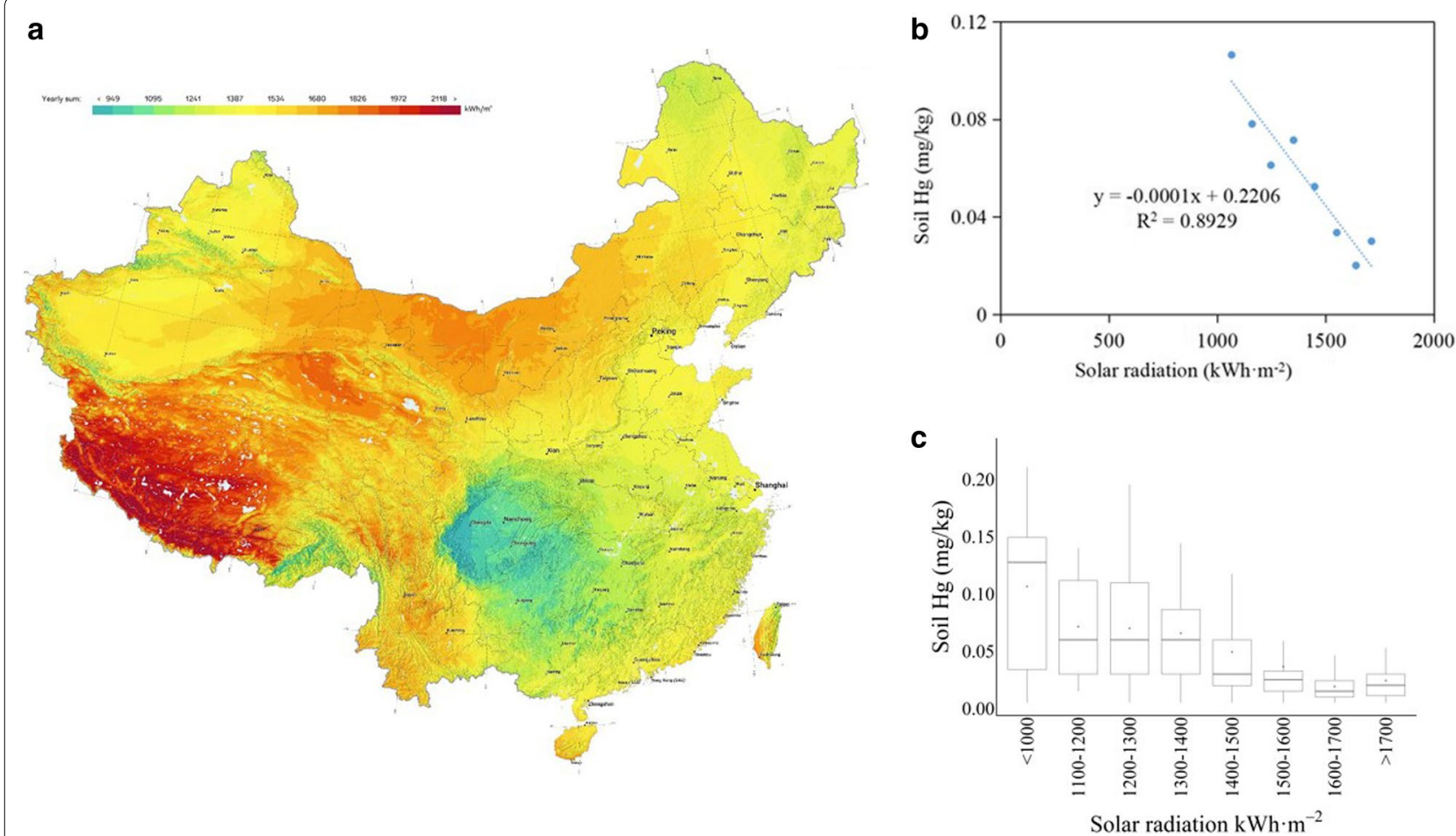

Fig. 4 The maps of solar radiation in China and relationship of $\mathrm{Hg}$ levels in surface soil with solar radiation. Spatial distribution of a solar radiation in China; significant relationships between soil $\mathrm{Hg}$ level and solar radiation (b); median, range, upper quartile, and lower quartile of soil $\mathrm{Hg}$ for each interval of solar radiation $(\mathbf{c})$

has been observed in the western United States [7]. In northeastern and southwestern China, the distribution of $\mathrm{Hg}$ in these regions was geographically coincident with the contents of SOM, especially in northeastern China (Figs. 1 and 2h) [55]. High $\mathrm{Hg}$ levels were observed in the northeastern regions, although wet deposition was relatively low (400-800 $\mathrm{mm})$. Soils covered by forests and enrichment in organic matter enhanced $\mathrm{Hg}$ deposition by litterfall and throughfall, simultaneously depleting $\mathrm{Hg}$ emissions. In highly organic regions (peat bog ecosystems), it is estimated that dry deposition of gaseous elemental mercury is dominant $(\sim 80 \%)$ over wet deposition ( 20\%) [56].

\section{Mercury emissions from soils}

The solar radiation intensity in China declined from the northwest to the southeast (Fig. 4a), and a strong negative correlation $\left(R^{2}=0.89\right)$ was observed between the soil $\mathrm{Hg}$ level and solar radiation (Fig. 4b), which indicated that increasing solar radiation would accelerate the emissions of $\mathrm{Hg}$ from the soil to the atmosphere. It is commonly accepted that gaseous elemental $\mathrm{Hg}$ emissions from soil are one of the most important processes of $\mathrm{Hg}$ losses in terrestrial environments [16, 57]. Solar radiation, which induces photoreduction, is the most common and pronounced factor for gaseous elemental Hg emissions. Many studies have identified a positive relationship that is attributed to a photochemically mediated reduction that coverts soil $\mathrm{Hg}$ (II) to volatile element $\mathrm{Hg}$ [50], although other biotic (microorganisms) and abiotic (organic matter) factors reduced $\mathrm{Hg}$ as well [58]. In comparison to direct radiation on bare soil, indirect radiation due to vegetation cover could decrease the role of solar radiation in $\mathrm{Hg}$ emissions [31]. Desertified lands (sand desert and Gobi Desert) in northwestern China have bare soils. Direct solar radiation due to poor vegetation cover in northwestern China was one of the contributors to low soil Hg levels.

In addition, the positive association between soil clay content and $\mathrm{Hg}$ concentration [51] suggested that atmospheric $\mathrm{Hg}$ was hardly sequestrated into deserted and sandy soils with low clay content in northwest China, which has arid and semi-arid climate [55].

\section{Factors controlling soil $\mathrm{Hg}$ distribution in China}

We hypothesize that the spatial variability in soil $\mathrm{Hg}$ levels in China is potentially caused by the balance between wet depositions associated with the East Asian summer monsoon, dry deposition associated with forest/ 
vegetation cover and inhibited emissions associated with SOM and solar radiation.

The model of the distribution of soil $\mathrm{Hg}$ was established by multiple linear regression as follows:

$$
\begin{aligned}
\log (\mathrm{Hg})= & -2.809+9.398 \times 10^{-4} \times(P) \\
& +1.1774 \times 10^{-1} \times(\mathrm{NDVI}) \\
& +8.879 \times 10^{-2} \times \log (\mathrm{SOM}) \\
& -9.897 \times 10^{-5} \times(\mathrm{SR}) \\
& \mathrm{P}<0.01, R^{2}=0.51
\end{aligned}
$$

where $\mathrm{Hg}$ is the soil $\mathrm{Hg}$ level $(\mathrm{mg} / \mathrm{kg})$ in the $0-20 \mathrm{~cm}$ surface soil, $P$ is the average annual precipitation $(\mathrm{mm})$, SOM is the SOM (\%), NDVI is the Normalized Difference Vegetation Index, and SR is solar radiation $(\mathrm{kWh} /$ $\mathrm{m}^{2}$ ). Both simple regression analysis of soil $\mathrm{Hg}$ with the first three variables and multiple linear regression analysis showed positive relationships, and solar radiation showed a negative relationship between the soil $\mathrm{Hg}$ level and those variables. Statistical analysis showed that the relative contributions of the four variables were ranked as follows: precipitation $(49.4 \%)>$ NDVI $(23.4 \%)>$ solar radiation $(17.9 \%)>$ SOM $(9.3 \%)$.

\section{Conclusions}

We suggest that wet deposition associated with the summer Asian monsoon, dry deposition associated with vegetation cover and inhibited emissions linked with SOM and photoreduction due to solar radiation are the key factors controlling $\mathrm{Hg}$ redistribution in terrestrial environments in China. Vegetation cover, SOM and solar radiation are key factors controlling $\mathrm{Hg}$ air/soil exchange, such as $\mathrm{Hg}$ emissions. Statistical analysis showed that of the factors affecting the soil surface $\mathrm{Hg}$ concentration, precipitation was the most important factor (49.4\%), followed by vegetation cover (23.4\%). The contributions of monsoons and vegetation cover to surface soil $\mathrm{Hg}$ would be helpful to understand the potential ecosystem and human health risks from $\mathrm{Hg}$ and to predict the trend in soil $\mathrm{Hg}$ in the future.

\section{Supplementary information}

Supplementary information accompanies this paper at https://doi. org/10.1186/s12302-020-00370-1.

Additional file 1: Figure $\mathbf{S 1}$. The relationships of soil $\mathrm{Hg}$ concentrations in Europe with (A) European precipitations and (B) soil organic carbon (SOC). The soil $\mathrm{Hg}$ data, precipitation and soil organic carbon used in this study are from the Geochemical Mapping of Agricultural Soils (GEMAS) project, which was carried out by the EuroGeoSurveys (EGS) Geochemistry Expert Group. The precipitation dataset Europe was separated into 19 subsets (sampling bin) with every $100 \mathrm{~mm} /$ year interval in $\mathrm{R}$, and the last subset contains all points with precipitation greater than $2200 \mathrm{~mm} /$ year. One hundred sample points were randomly selected from each subset and the average value of those points was taken as the representative of this subset. The soil organic carbon (SOC) dataset was divided into 13 subsets at interval of $1 \mathrm{~g} / \mathrm{kg}$ from 0 to $10 \mathrm{~g} / \mathrm{kg}, 10-13 \mathrm{~g} / \mathrm{kg}, 13-26 \mathrm{~g} /$ $\mathrm{kg}$ and last subset contains all points with SOC more than $26 \mathrm{~g} / \mathrm{kg}$. The average of the 200 randomly sampling points obtained for each sampling bin represents this subset. Figure S2. (A) vegetation cover (created using ArcGIS Geographic Information Systems software version 10.2, Environmental Systems Research Institute Inc, Redlands, Calif); (B) soil Hg map surveyed in 1994.

\section{Abbreviations}

Hg: Mercury; SOM: Soil organic matter; NDVI: Normalized Difference Vegetation Index; NMPRGS: National Multi-Purpose Regional Geochemical Survey; P: Average annual precipitation; SR: Solar radiation.

\section{Acknowledgements}

We gratefully thank Prof. Andrew A. Meharg for English-language editing.

\section{Authors' contributions}

ZYZ, GXS designed research and wrote the paper; GL, LY contributed data analysis; and XJW has substantively revised the manuscript. All authors read and approved the final manuscript.

\section{Funding}

This project was financially supported by the Natural Science Foundation of China (No. 41571130062), the National Key Research and Development Program of China (2017YFD0800303, 2016YFD0800400), Central Public-interest Scientific Institution Basal Research Fund (20160604).

\section{Availability of data and materials}

The datasets used and analyzed during the current study are available from the corresponding author on reasonable request.

\section{Ethics approval and consent to participate}

Not applicable.

\section{Consent for publication \\ Not applicable.}

\section{Competing interests \\ The authors declare no competing financial interest.}

\section{Author details}

${ }^{1}$ State Key Laboratory of Urban and Regional Ecology, Research Center for Eco-Environmental Sciences, Chinese Academy of Sciences, Beijing 100085, China. ${ }^{2}$ Key Laboratory of Urban Environment and Health, Institute of Urban Environment, Chinese Academy of Sciences, Xiamen 361021, China. ${ }^{3}$ University of Chinese Academy of Sciences, Beijing 100049, China. ${ }^{4}$ Research Center for Environmental Protection and Water and Soil Conservation, China Academy of Transportation Sciences, 240 \#, Huixinli, Chaoyang District, Beijing 100029, China.

Received: 18 April 2020 Accepted: 15 June 2020

Published online: 24 June 2020

\section{References}

1. Zhang H, Feng XB, Larssen T, Qiu GL, Vogt RD (2010) In inland China, rice, rather than fish, is the major pathway for methylmercury exposure. Environ Health Persp 118(9):1183-1188. https://doi.org/10.1289/ehp.1001915

2. Wang X, Lin CJ, Yuan W, Sommar J, Zhu W, Feng XB (2016) Emission-dominated gas exchange of elemental mercury vapor over natural surfaces in China. Atmos Chem Phys 16(17):11125-11143. https://doi.org/10.5194/ acp-16-11125-2016

3. Boening DW (2000) Ecological effects, transport, and fate of mercury: a general review. Chemosphere 40(12):1335-1351. https://doi.org/10.1016/ s0045-6535(99)00283-0 
4. Pirrone NMKR (2005) Where we stand on mercury pollution and its health effects on regional and global scales. Dynamics of mercury pollution on regional and global scales. Springer, US, Berlin, pp 1-21

5. Lindberg S, Bullock R, Ebinghaus R, Engstrom D, Feng XB, Fitzgerald W et al (2007) A synthesis of progress and uncertainties in attributing the sources of mercury in deposition. Ambio 36(1):19-32. https://doi. org/10.1579/0044-7447(2007)36\%5b19:asopau\%5d2.0.co;2

6. Eckley CS, Blanchard P, McLennan D, Mintz R, Sekela M (2015) Soil-air mercury flux near a large industrial emission source before and after closure (Flin Flon, Manitoba, Canada). Environ Sci Technol 49(16):97509757. https://doi.org/10.1021/acs.est.5b01995

7. Obrist D, Pearson C, Webster J, Kane T, Lin CJ, Aiken GR et al (2016) A synthesis of terrestrial mercury in the western United States: spatial distribution defined by land cover and plant productivity. Sci Total Environ 568:522-535. https://doi.org/10.1016/j.scitotenv.2015.11.104

8. Liu M, Zhang Q, Cheng M, He Y, Chen L, Zhang H et al (2019) Rice life cycle-based global mercury biotransport and human methylmercury exposure. 10(1):5164

9. Rea AW, Keeler GJ, Scherbatskoy T (1996) The deposition of mercury in throughfall and litterfall in the lake champlain watershed: a short-term study. Atmos Environ 30(19):3257-3263. https://doi.org/10.1016/13522310(96)00087-8

10. Kuiken T, Gustin M, Zhang H, Lindberg S, Sedinger B (2008) Mercury emission from terrestrial background surfaces in the eastern USA. II: air/surface exchange of mercury within forests from South Carolina to New England. Appl Geochem 23(3):356-368. https://doi.org/10.1016/j. apgeochem.2007.12.007

11. Wan Q, Feng XB, Lu J, Zheng W, Song XJ, Li P et al (2009) Atmospheric mercury in Changbai Mountain area, northeastern China II. The distribution of reactive gaseous mercury and particulate mercury and mercury deposition fluxes. Environ Res 109(6):721-727. https://doi. org/10.1016/j.envres.2009.05.006

12. Driscoll CT, Mason RP, Chan HM, Jacob DJ, Pirrone N (2013) Mercury as a global pollutant: sources, pathways, and effects. Environ Sci Technol 47(10):4967-4983. https://doi.org/10.1021/es305071v

13. Tseng CM, Lamborg CH, Hsu SC (2013) A unique seasonal pattern in dissolved elemental mercury in the South China Sea, a tropical and monsoon-dominated marginal sea. Geophys Res Lett 40(1):167-172. https://doi.org/10.1029/2012gl054457

14. Wang X, Bao ZD, Lin CJ, Yuan W, Feng XB (2016) Assessment of global mercury deposition through litterfall. Environ Sci Technol 50(16):85488557. https://doi.org/10.1021/acs.est.5b06351

15. Li P, Feng XB, Qiu GL, Shang LH, Li ZG (2009) Mercury pollution in Asia: a review of the contaminated sites. J Hazard Mater 168(2-3):591-601. https://doi.org/10.1016/j.jhazmat.2009.03.031

16. Wang SF, Feng XB, Qiu GL, Wei ZQ, Xiao TF (2005) Mercury emission to atmosphere from Lanmuchang $\mathrm{Hg}-\mathrm{Tl}$ mining area, Southwestern Guizhou. China Atmos Environ 39(39):7459-7473. https://doi. org/10.1016/j.atmosenv.2005.06.062

17. Wang $X$, Yuan Wei, Lin Che-Jen, Zhang Leiming, Zhang Hui, Feng $X$ (2019) Climate and vegetation as primary drivers for global mercury storage in surface soil. Environ Sci Technol 53(18):10665-10675. https ://doi.org/10.1021/acs.est.9b02386

18. Streets DG, Zhang Q, Wu Y (2009) Projections of global mercury emissions in 2050. Environ Sci Technol 43(8):2983-2988. https://doi. org/10.1021/es802474j

19. Pacyna EG, Pacyna JM, Sundseth K, Munthe J, Kindbom K, Wilson $\mathrm{S}$ et al (2010) Global emission of mercury to the atmosphere from anthropogenic sources in 2005 and projections to 2020. Atmos Environ 44(20):2487-2499. https://doi.org/10.1016/j.atmosenv.2009.06.009

20. Streets DG, Devane MK, Lu ZF, Bond TC, Sunderland EM, Jacob DJ (2011) All-time releases of mercury to the atmosphere from human activities. Environ Sci Technol 45(24):10485-10491. https://doi. org/10.1021/es202765m

21. Li M, Xi XH, Xiao GY, Cheng HX, Yang ZF, Zhou GH et al (2014) National multi-purpose regional geochemical survey in China. J Geochem Explor 139:21-30. https://doi.org/10.1016/j.gexplo.2013.06.002

22. Muntean M, Janssens-Maenhout G, Song SJ, Selin NE, Olivier JGJ, Guizzardi D et al (2014) Trend analysis from 1970 to 2008 and model evaluation of EDGARv4 global gridded anthropogenic mercury emissions. Sci Total Environ 494:337-350. https://doi.org/10.1016/j. scitotenv.2014.06.014

23. Liu R, Shang R, Liu Y, Lu X (2015) Globally comparing approaches for gap filling of temporal data to generate the continuous vegetation parameters, submission to Remote Sensing of Environment

24. Holben BN (1986) Characteristics of maximum-value composite images from temporal AVHRR data. Int J Remote Sens 7(11):1417-1434

25. Selin NE (2009) Global biogeochemical cycling of mercury: a review. Annu Rev Env Resour 34:43-63. https://doi.org/10.1146/annurev.envir on.051308.084314

26. Yu B, Wang X, Lin CJ, Fu XW, Zhang H, Shang LH et al (2015) Characteristics and potential sources of atmospheric mercury at a subtropical near-coastal site in East China. J Geophys Res-Atmos 120(16):8563-8574. https://doi.org/10.1002/2015jd023425

27. Fu XW, Zhang H, Yu B, Wang X, Lin CJ, Feng XB (2015) Observations of atmospheric mercury in China: a critical review. Atmos Chem Phys 15(16):9455-9476. https://doi.org/10.5194/acp-15-9455-2015

28. Huang J, Kang SC, Zhang QG, Yan HY, Guo JM, Jenkins MG et al (2012) Wet deposition of mercury at a remote site in the Tibetan Plateau: concentrations, speciation, and fluxes. Atmos Environ 62:540-550. https ://doi.org/10.1016/j.atmosenv.2012.09.003

29. Mahajan BA, Srinivasan M (1988) Mercury pollution in the estuarine region around Bombay-Island. Environ Technol Lett 9(4):331-336. https:// doi.org/10.1080/09593338809384574

30. Licht A, van Cappelle M, Abels HA, Ladant JB, Trabucho-Alexandre J, France-Lanord C et al (2014) Asian monsoons in a late eocene greenhouse world. Nature 513(7519):501-506. https://doi.org/10.1038/natur e13704

31. Ariya PA, Amyot M, Dastoor A, Deeds D, Feinberg A, Kos G et al (2015) Mercury physicochemical and biogeochemical transformation in the atmosphere and at atmospheric interfaces: a review and future directions. Chem Rev 115(10):3760-3802. https://doi.org/10.1021/cr500667e

32. Zhang H, Fu XW, Lin CJ, Wang X, Feng XB (2015) Observation and analysis of speciated atmospheric mercury in Shangri-La, Tibetan Plateau, China. Atmos Chem Phys 15(2):653-665. https://doi.org/10.5194/ acp-15-653-2015

33. Holmes CD, Krishnamurthy NP, Caffrey JM, Landing WM, Edgerton ES, Knapp KR et al (2016) Thunderstorms increase mercury wet deposition. Environ Sci Technol 50(17):9343-9350. https://doi.org/10.1021/acs. est.6b02586

34. Shi J, Wen KM, Cui LL (2016) Patterns and trends of high-impact weather in China during 1959-2014. Nat Hazard Earth Sys 16(3):855-869. https:// doi.org/10.5194/nhess-16-855-2016

35. Jang J, Han S (2011) Importance of monsoon rainfall in mass fluxes of filtered and unfiltered mercury in Gwangyang Bay, Korea. Sci Total Environ 409(8):1498-1503. https://doi.org/10.1016/j.scitotenv.2011.01.003

36. Mason RP, Lawson NM, Sullivan KA (1997) Atmospheric deposition to the Chesapeake Bay watershed_-regional and local sources. Atmos Environ 31(21):3531-3540. https://doi.org/10.1016/S1352-2310(97)00207-0

37. Landis MS, Keeler GJ (2002) Atmospheric mercury deposition to Lake Michigan during the Lake Michigan mass balance study. Environ Sci Technol 36(21):4518-4524. https://doi.org/10.1021/es011217b

38. Ericksen JA, Gustin MS, Schorran DE, Johnson DW, Lindberg SE, Coleman JS (2003) Accumulation of atmospheric mercury in forest foliage. Atmos Environ 37(12):1613-1622. https://doi.org/10.1016/S1352-2310(03)00008 $-6$

39. Zhang $L M$, Wright $L P$, Blanchard $P$ (2009) A review of current knowledge concerning dry deposition of atmospheric mercury. Atmos Environ 43(37):5853-5864. https://doi.org/10.1016/j.atmosenv.2009.08.019

40. Ma M, Wang DY, Du HX, Sun T, Zhao Z, Wei SQ (2015) Atmospheric mercury deposition and its contribution of the regional atmospheric transport to mercury pollution at a national forest nature reserve, southwest China. Environ Sci Pollut R 22(24):20007-20018. https://doi.org/10.1007/ s11356-015-5152-9

41. Gustin MS, Ericksen JA, Schorran DE, Johnson DW, Lindberg SE, Coleman JS (2004) Application of controlled mesocosms for understanding mercury air-soil-plant exchange. Environ Sci Technol 38(22):6044-6050. https ://doi.org/10.1021/es0487933

42. Zhou J, Feng XB, Liu HY, Zhang H, Fu XW, Bao ZD et al (2013) Examination of total mercury inputs by precipitation and litterfall in a remote upland 
forest of Southwestern China. Atmos Environ 81:364-372. https://doi. org/10.1016/j.atmosenv.2013.09.010

43. Wang X, Lin CJ, Lu ZY, Zhang H, Zhang YP, Feng XB (2016) Enhanced accumulation and storage of mercury on subtropical evergreen forest floor: implications on mercury budget in global forest ecosystems. J Geophys Res-Biogeo 121(8):2096-2109. https://doi.org/10.1002/2016jg003446

44. St Louis VL, Rudd JWM, Kelly CA, Hall BD, Rolfhus KR, Scott KJ et al (2001) Importance of the forest canopy to fluxes of methyl mercury and total mercury to boreal ecosystems. Environ Sci Technol 35(15):3089-3098. https://doi.org/10.1021/es001924p

45. Shanley JB, Engle MA, Scholl M, Krabbenhoft DP, Brunette R, Olson ML et al (2015) High mercury wet deposition at a "clean air" site in Puerto Rico. Environ Sci Technol 49(20):12474-12482. https://doi.org/10.1021/ acs.est.5b02430

46. Fu XW, Zhu W, Zhang H, Sommar J, Yu B, Yang X et al (2016) Depletion of atmospheric gaseous elemental mercury by plant uptake at Mt. Changbai. Northeast China. Atmos Chem Phys 16(20):12861-12873. https://doi. org/10.5194/acp-16-12861-2016

47. Zhang QG, Huang J, Wang FY, Mark LW, Xu JZ, Armstrong D et al (2012) Mercury distribution and deposition in glacier snow over western China. Environ Sci Technol 46(10):5404-5413. https://doi.org/10.1021/es300166x

48. Xun W (2017) Global review of mercury biogeochemical processes in forest ecosystems. Progress Chem 29(19):970-980

49. Kuiken T, Zhang H, Gustin M, Lindberg S (2008) Mercury emission from terrestrial background surfaces in the eastern USA. Part I: air/surface exchange of mercury within a southeastern deciduous forest (Tennessee) over one year. Appl Geochem 23(3):345-355. https://doi.org/10.1016/j. apgeochem.2007.12.006

50. Amyot M, Mcqueen DJ, Mierle G, Lean DRS (1994) Sunlight-induced formation of dissolved gaseous mercury in lake waters. Environ Sci Technol 28(13):2366-2371

51. Obrist D, Johnson DW, Lindberg SE, Luo Y, Hararuk O, Bracho R et al (2011) Mercury distribution across 14 US forests. Part I: spatial patterns of concentrations in biomass, litter, and soils. Environ Sci Technol 45(9):39743981. https://doi.org/10.1021/es104384m

52. Schuster PF, Schaefer KM, Aiken GR, Antweiler RC, Dewild JF, Gryziec JD et al (2018) Permafrost stores a globally significant amount of mercury. Geophys Res Lett 45(3):1463-1471. https://doi.org/10.1002/2017gl0755 71

53. Mauclair C, Layshock J, Carpi A (2008) Quantifying the effect of humic matter on the emission of mercury from artificial soil surfaces. Appl Geochem 23(3):594-601. https://doi.org/10.1016/j.apgeochem.2007.12.017

54. Matthiessen A (1998) Reduction of divalent mercury by humic substances-kinetic and quantitative aspects. Sci Total Environ 213(13):177-183. https://doi.org/10.1016/S0048-9697(98)00090-4

55. Sun GX, Meharg AA, Li G, Chen Z, Yang L, Chen SC et al (2016) Distribution of soil selenium in China is potentially controlled by deposition and volatilization? Sci Rep-UK 6:1-9. https://doi.org/10.1038/srep20953
56. Enrico M, Le Roux G, Marusczak N, Heimburger LE, Claustres A, Fu XW et al (2016) Atmospheric mercury transfer to peat bogs dominated by gaseous elemental mercury dry deposition. Environ Sci Technol 50(5):2405-2412. https://doi.org/10.1021/acs.est.5b06058

57. Schluter K (2000) Review: evaporation of mercury from soils. An integration and synthesis of current knowledge. Environ Geol 39(3-4):249-271. https://doi.org/10.1007/s002540050005

58. Poulain AJ, Roy V, Amyot M (2007) Influence of temperate mixed and deciduous tree covers on $\mathrm{Hg}$ concentrations and photoredox transformations in snow. Geochim Cosmochim Ac 71(10):2462

59. Fu XW, Feng XB, Zhu WZ, Rothenberg S, Yao H, Zhang H (2010) Elevated atmospheric deposition and dynamics of mercury in a remote upland forest of southwestern China. Environ Pollut 158(6):2324-2333. https:// doi.org/10.1016/j.envpol.2010.01.032

60. Agnan Y, Le Dantec T, Moore CW, Edwards GC, Obrist D (2016) New constraints on terrestrial surface atmosphere fluxes of gaseous elemental mercury using a global database. Environ Sci Technol 50(2):507-524. https://doi.org/10.1021/acs.est5b04013

61. Pan L, Lin CJ, Carmichael GR, Streets DG, Tang YH, Woo JH et al (2010) Study of atmospheric mercury budget in East Asia using STEM-Hg modeling system. Sci Total Environ 408(16):3277-3291. https://doi. org/10.1016/j.scitotenv.2010.04.039

62. Feng XB, Wang SF, Qiu GA, Hou YM, Tang SL (2005) Total gaseous mercury emissions from soil in Guiyang, Guizhou, China. J Geophys Res-Atmos. https://doi.org/10.1029/2004JD005643

63. Xiao ZF, Sommar J, Lindqvist O, Tan H, He JL (1998) Atmospheric mercury deposition on Fanjing Mountain nature reserve, Guizhou. China. Chemosphere 36(10):2191-2200. https://doi.org/10.1016/S0045-6535(97)10191-6

64. Tan H, He JL, Liang L, Lazoff S, Sommer J, Xiao ZF et al (2000) Atmospheric mercury deposition in Guizhou. China. Sci Total Environ 259(1-3):223230. https://doi.org/10.1016/50048-9697(00)00584-2

65. Guo YN, Feng XB, Li ZG, He TR, Yan HY, Meng B et al (2008) Distribution and wet deposition fluxes of total and methyl mercury in Wujiang River Basin, Guizhou. China Atmos Environ 42(30):7096-7103. https://doi. org/10.1016/j.atmosenv.2008.06.006

66. Fu XW, Feng XB, Zhang H, Yu B, Chen LG (2012) Mercury emissions from natural surfaces highly impacted by human activities in Guangzhou province, South China. Atmos Environ 54:185-193. https://doi.org/10.1016/j. atmosenv.2012.02.008

67. Liu F, Cheng HX, Yang K, Zhao CD, Liu YH, Peng M et al (2014) Characteristics and influencing factors of mercury exchange flux between soil and air in Guangzhou City. J Geochem Explor 139:115-121. https://doi. org/10.1016/j.gexplo.2013.09.005

\section{Publisher's Note}

Springer Nature remains neutral with regard to jurisdictional claims in published maps and institutional affiliations.

\section{Submit your manuscript to a SpringerOpen ${ }^{\circ}$ journal and benefit from:}

- Convenient online submission

- Rigorous peer review

- Open access: articles freely available online

- High visibility within the field

- Retaining the copyright to your article

Submit your next manuscript at $\boldsymbol{\nabla}$ springeropen.com 